\title{
Perbandingan Pengaruh Latihan Bench Press dan Push Up terhadap Peningkatan Keterampilan Chest Pass
}

\author{
Comparison of the Effects of Bench Press and Push Up Exercises \\ on Chest Pass Skill Improvement
}

\author{
Pulung Riyanto \\ Universitas Subang, Subang, Jawa Barat, Indonesia \\ riyantopul@unsub.ac.id
}

\begin{abstract}
Abstrak
Permainan bola basket dilakukan dengan mempergunakan tiga unsur teknik yang menjadi pokok permainan, yakni : mengoper (passing), menangkap bola (catching), menggiring bola (dribbling), dan menembakan bola ke keranjang (shooting). Ketiga unsur teknik berkembang menjadi bermacam-macam teknik lanjutan yang memungkinkan permainan bola basket bervariasi. Misalnya, dalam teknik mengoper dan menangkap bola terdapat beberapa cara seperti : lemparan dada (chest pass), lemparan dari atas kepala (overhead pass), lemparan pantul (bounce pass), dan lain sebagainya. Seorang pemain bola basket yang sudah menguasai dan terampil dalam permainan bola basket harus memiliki kondisi fisik yang baik. Salah satu unsur kemampuan fisik yang penting dalam permainan bola basket adalah power/kekuatan. Seorang pemain bola basket mampu melakukan passing chest pass, bounce pass, over head pass dengan cepat dan tepat berarti atlet telah memiliki kekuatan otot lengan yang terlatih karena atlet tersebut sudah mempersiapkannya secara matang sebelum menghadapi pertandingan. Metode yang digunakan adalah metode eksperimen, sedangkan sampel yang dijadikan sampelnya adalah siswa SMA Negeri 3 Subang. Proses latihan berlangsung selama dua bulan, dan dilatih sesuai dengan program latihan . Berdasarkan hasil penghitungan dan analisis data yang telah diuraikan maka kesimpulan dalam penelitian ini adalah Terdapat pengaruh yang signifikan dari latihan bench press terhadap hasil chest pass dalam permainan bola basket di SMA Negeri 3 Subang.Terdapat pengaruh yang signifikan dari latihan push up terhadap hasil chest pass dalam permainan bola basket di SMA Negeri 3 Subang. Latihan bench press lebih signifikan pengaruhnya terhadap keterampilan chest pass dibandingkan dengan latihan push up.
\end{abstract}

Kata Kunci : bench press, keterampilan chest pass, push up

\begin{abstract}
Basketball games are carried out by using three technical elements which are the main points of the game, namely: passing, catching the ball (catching), dribbling (dribbling), and shooting the ball into the basket (shooting). The three elements of engineering develop into various advanced techniques that allow basketball games to vary. For example, in the technique of passing and catching a ball there are several ways such as: chest passes, throws from the top of the head (overhead pass), bounce passes (bounce passes), and so forth. A basketball player who has mastered and is skilled in basketball games must have good physical condition. One important element of physical ability in basketball is power. A basketball player is capable of passing chest pass, bounce pass, over head pass quickly and precisely means that the athlete has trained arm muscle strength because the athlete has prepared it carefully before facing the match. The method
\end{abstract}


used is the experimental method, while the sample used is the students of Subang 3 High School. The training process lasted two months, and was trained according to the training program. Based on the results of the calculation and analysis of the data that has been described, the conclusions in this study are that there is a significant effect of the bench press exercise on the results of chest passes in basketball games in SMA 3 Subang. There is a significant influence of push up exercises on the results of chest passes in basketball game at Subang 3 Public High School. Benchmark exercise has a more significant effect on chest pass skills compared to push up exercises.

Keywords: bench press, chest pass skills, push ups

\section{PENDAHULUAN}

Olahraga bola basket adalah salah satu bentuk olahraga yang termasuk permainan. Bola basket ini mengalami perkembangan yang cukup baik di Indonesia pada saat ini. Klub-klub bola basket di tanah air berdiri, dan mengikuti kompetisi resmi dari PERBASI. Klub-klub lokal atau daerah pun bagaikan jamur di musim hujan, banyak tumbuh dan berkembangan di mana-mana. Atas dasar perkembangan bola basket seperti itulah mendorong para pembina olahraga, guru penjas, pelatih dan pencinta olahraga untuk mengembangan olahraga bola basket ini dengan baik.

Permainan bola basket dilakukan dengan mempergunakan tiga unsur teknik yang menjadi pokok permainan, yakni : mengoper (passing), menangkap bola (catching), menggiring bola (dribbling), dan menembakan bola ke keranjang (shooting). Ketiga unsur teknik tadi berkembang menjadi bermacam-macam teknik lanjutan yang memungkinkan permainan bola basket hidup dan bervariasi. Misalnya, dalam teknik mengoper dan menangkap bola terdapat beberapa cara seperti : lemparan dada (chest pass), lemparan dari atas kepala (overhead pass), lemparan pantul (bounce pass), dan lain sebagainya. Teknik dasar bermain bola basket tersebut dapat dikuasai dengan melakukan latihan. Proses latihan hendaklah sesuai dengan prinsip-prinsip latihan, yaitu sistematis, kontinu, dan juga overload. Proses latihan tidak sesuai dengan prinsip-prinsip tersebut, maka hasil latihan yang dilakukan tidak akan mencapai hasil yang maksimal.

Training menurut Harsono (1988) adalah "Proses yang sistematis dari berlatih atau bekerja, yang harus dilakukan secara berulang-ulang, dengan kian hari kian menambah jumlah beban latihan atau pekerjaannya." Seorang pemain bola basket yang sudah menguasai dan terampil dalam permainan bola basket harus memiliki kondisi fisik yang baik. Salah satu unsur kemampuan fisik yang penting dalam permainan bola basket adalah power/kekuatan. Seorang pemain bola basket mampu melakukan passing chest pass, bounce pass, over head pass dengan cepat dan tepat berarti atlet telah memiliki kekuatan otot lengan yang terlatih karena atlet tersebut sudah mempersiapkannya secara matang sebelum menghadapi pertandingan. Pengalaman penulis berdasarkan analisis penelitian di lapangan bahwa untuk mendukung hal tersebut, pelatih 
menggunakan bentuk-bentuk latihan yang mengarah kepada kekuatan dan latihan beban (weight training).

Berdasarkan analisis penulis, latihan beban yang sering diterapkan oleh pelatih terhadap atlet menggunakan dua jenis, yaitu latihan dengan alat bantu seperti besi (dumbell) dan latihan beban dengan tubuh sendiri. Latihan weight training, penulis memfokuskan pada bentuk latihan yang sering digunakan seperti bench press dan push up, karena dua bentuk latihan tersebut merupakan latihan yang bertujuan untuk meningkatkan kekuatan otot lengan.

Bentuk latihan yang penulis coba berikan didasari pada beberapa analisis pada pemain bola basket yang tergabung dalam tim ekstrakurikuler bola basket di sekolah yang penulis bina. Hasil analisis tersebut adalah sebagai berikut:

1. Pemain adalah tergabung dalam tim bola basket.

2. Pemain memiliki teknik dasar yang relatif baik, khususnya teknik chest pass.

3. Teknik chest pass yang dilakukan oleh pemain pada saat latihan, bila dipersentasikan hampir $80 \%$ tidak memiliki power yang cukup sehingga hasilnya kurang maksimal.

Mengacu kepada hasil analisis penulis di lapangan pada setiap pemain, maka penulis beranggapan perlu kiranya melatih komponen kondisi fisik yang dapat menambah power lengan. Bentuk latihan yang dimaksud oleh penulis adalah latihan push-up dan latihan bench press. Latihan ini didasari bahwa pada saat melakukan chest pass dibutuhkan power lengan yang bagus, khususnya otot tricep dan bicep. Berdasarkan pemaparan di atas, penulis berkeinginan untuk mengetahui apakah latihan bench press dan push up memberikan pengaruh yang signifikan terhadap peningkatan chest pass dalam permainan bola basket. Hal ini penulis angkat dalam penelitian ini karena tidak sedikit pelatih menggunakan bentuk latihan tersebut untuk melatih power lengan.

Latihan yang dilakukan dalam setiap cabang olahraga harus mengacu pada prinsip-prinsip latihan, agar dapat meningkatkan prestasi yang diinginkan dalam setiap cabang olahraga. Latihan yang tepat akan meningkatkan prestasi dan dapat memberikan kontribusi yang lebih terhadap peningkatan komponen kondisi fisik, sehingga kualitas gerak dan fungsi organ-organ tubuh meningkat.

Komponen kondisi fisik terdiri dari berbagai macam, seperti daya tahan, stamina, kelentukan, kelincahan, strength dan power. Komponen tersebut harus terprogram dan terencana dalam proses latihannya agar bermanfaat dalam mencapai prestasi yang lebih baik.Harsono (1988 : 153) menjelaskan sebagai berikut : 
Kondisi fisik atlet memegang peranan yang sangat penting dalam program latihannya. Program latihan kondisi fisik haruslah direncanakan secara baik dan sistematis dan ditujukan untuk meningkatkan kesegaran jasmani dan kemampuan fungsional dari sistem tubuh sehingga dengan demikian memungkinkan atlet untuk mnecapai prestasi yang lebih baik.

Keuntungan yang didapat dari keadaan kondisi fisik yang baik, seperti yang diutarakan oleh Hasono (1988) lebih lanjut, sebagai berikut :

1. Ada peningkatan dalam kemampuan sistem sirkulasi dan kerja jantung.

2. Ada peningkatan dalam kekuatan, kelentukan, stamina, kecepatan dan lain-lain komponen kondisi fisik.

3. Ada pemulihan ekonomi gerak yang lebih baik pada waktu latihan.

4. Ada pemulihan yang lebih cepat dalam organ-organ tubuh setelah latihan.

5. Ada respons yang sepat dari organisme tubuh kita apabila sewaktu-waktu respons demikian diperlukan.

Bentuk latihan untuk meningkatkan power lengan di antaranya adalah dengan melakukan latihan bench press dan push up. Gerakannya latihan yang penulis maksud adalah sebagai berikut :

A. Bench Press

Bench press adalah latihan mendorong atau mengangkat beban dengan kedua lengan pada posisi tidur. Bebannya dapat ditambah dalam setiap latihannya yang berfungsi untuk meningkatkan otot dada, triceps, pectoralis mayor, pectoralis minor, corabra drialis, biceps atas deltoid anterior, sirratus anterior. Latihan bench press dibantu dengan alat/beban berupa barbell.

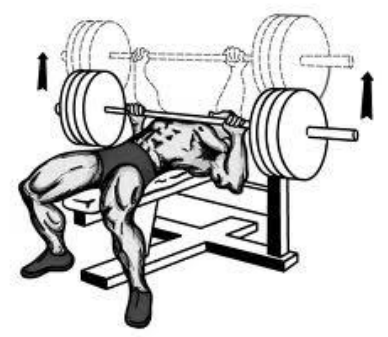

\section{Gambar 1. Bentuk Gerakan Latihan Bench Press}

Sikap bench press dimulai dengan posisi tidur terlentang dengan kedua kaki dibuka, tangan bersiap untuk mengangkat beban. Angkat beban sampai kedua lengan lurus ke atas dan berhenti untuk beberapa saat. Turunkan beban sedikit demi sedikit sampai tangan dan beban pada posisi semula. 


\section{B. Push up}

Push up adalah tidur tengkurap dengan membengkokkan kedua lengan dan bertumpu pada telapak tangan, kedua tangan diluruskan dan bertumpu pada ujung jari kaki lalu melakukan gerakan naik turun secara berulang-ulang. Latihan ini berfungsi untuk meningkatkan power lengan, khususnya otot biceps dan triceps.

Posisi awal tidur tengkurap dengan tangan di sisi kanan kiri badan. Badan didorong ke atas dengan kekuatan tangan. Posisi kaki dan badan tetap lurus atau tegap. Badan diturunkan dengan tetap menjaga kondisi badan dan kaki tetap lurus. Badan turun tanpa menyentuh lantai atau tanah, naik lagi dan dilakukan secara berulang-ulang. Kegiatan ini dapat dikombinasikan dengan cara:

○ Mengubah jarak telapak tangan.

○ Bentuk tangan yang menyentuh lantai: membuka, mengepal, menggunakan jari, atau punggung tangan.

○ Mengubah jarak antar kakii

○ Mengubah ketinggian letak kaki: dengan menggunakan kursi atau kaki yang satu ditindihkan ke kaki yang lain.

Chu (1996) mengemukakan cara pelaksanaan latihan push up adalah : "Latihan ini dilakukan dengan posisi push up (telungkup), lengan dipanjangkan, tangan bertepuk pada waktu berada di atas, dan kembali pada posisi awal". Untuk lebih jelas latihan push up dapat dilihat pada gambar dibawah ini :

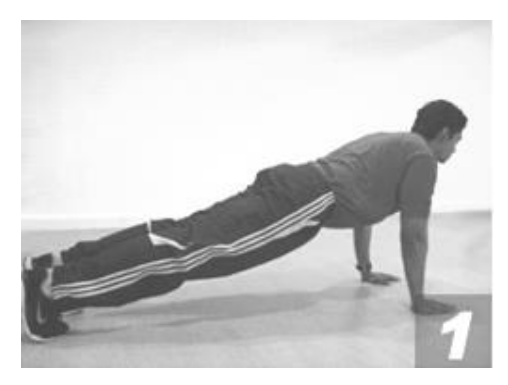

Gambar 2. Sikap Awal Push Up

Sikap ini dimulai dari kaki, badan dan kepala lurus di bawah dan posisi tangan rapat di samping badan. Pada posisi ini otot biceps dan triceps rileks karena belum ada beban yang bekerja. 


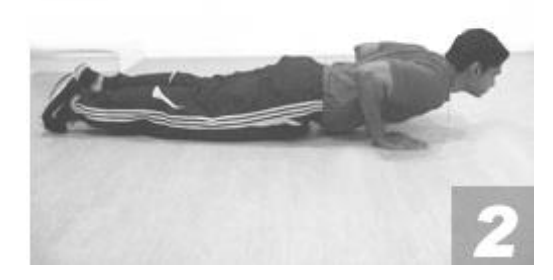

Gambar 3. Sikap Akhir Push Up

Gerakan push up pada saat sikap ini harus sama-sama pada saat diangkatnya, sehingga akan terlihat lurus dari mulai kaki sampai kepala. Otot yang bekerja pada sikap ini adalah otot bicep.

\section{METODE PENELITIAN}

Metode yang digunakan penulis ini adalah metode eksperimen. Tujuan dari penelitian eksperimen ini ingin mengetahui pengaruh latihan bench press dan push up terhadap keterampilan chest pass dalam permainan bola basket. Penelitian ini menggunakan suatu desain yang mempermudah pelaksanaan tahapan penelitian yaitu dengan desain pretes dan postes. Teknik pengambilan sampel tersebut, terpilihlah sejumlah sampel yang dikehendaki, yaitu sejumlah 40 siswa berdasarkan hasil lotre/undian. Untuk membagi sampel menjadi kelompok A dan kelompok B penuis menggunakan cara sebagai berikut : berdasarkan hasil rangking tes awal (lompat jauh), selanjutnya hasil rangking tersebut dipilihlah teknik A - B - B - A. Instrument yang digunakan dalam penelitian ini adalah tes operan dada (chest pass) ke dinding (wall pass).

\section{HASIL DAN PEMBAHASAN}

Data yang diperoleh melalui tes awal dan tes akhir selanjutnya diolah dan dianalisis. Langkah pertama, menghitung data hasil tes awal dan tes akhir untuk mencari nilai rata-rata dan simpangan baku kedua kelompok yang dibandingkan. Hasil penghitungan nilai rata-rata $(\overline{\mathrm{X}})$ dan simpangan baku (S) tersebut dapat dilihat pada tabel berikut

\section{Tabel 1}

Tabel Penghitungan Nilai Rata-rata, Simpangan Baku

Tes Awal dan Tes Akhir Kedua Kelompok Sampel

\begin{tabular}{|c|l|c|c|c|c|}
\hline \multirow{2}{*}{ Klp } & \multicolumn{2}{|c|}{ Variabel penelitian } & \multicolumn{2}{|c|}{ Tes Awal } & \multicolumn{2}{c|}{ Tes Akhir } \\
\cline { 3 - 6 } & & $\overline{\mathrm{X}}$ & $\mathrm{S}$ & $\overline{\mathrm{X}}$ & $\mathrm{S}$ \\
\hline \hline $\mathrm{A}$ & Latihan bench press & 10,75 & 1,07 & 13,1 & 1,12 \\
\hline $\mathrm{B}$ & Latihan push up & 11,15 & 1,22 & 12,35 & 1,27 \\
\hline
\end{tabular}


Langkah kedua, menghitung normalitas data. Hasil penghitungan uji normalitas dengan menggunakan uji Liliefors dapat dimanfaatkan untuk menentukan langkah analisis berikutnya, apakah menggunakan statistik parametrik atau non parametrik. Data hasil penghitungan uji normalitas dapat dilihat pada tabel berikut

Tabel 2

\section{Hasil Penghitungan Uji Normalitas Data Pada Kedua Kelompok Sampel}

\begin{tabular}{|c|l|c|c|c|c|}
\hline Klp & \multicolumn{1}{|c|}{ Variabel penelitian } & $\begin{array}{c}\text { Tes } \\
\text { Awal }\end{array}$ & $\begin{array}{c}\text { Tes } \\
\text { akhir }\end{array}$ & L tabel & Kesimpulan \\
\hline \hline A & Latihan bench press & 0,208 & 0,1853 & 0,220 & Normal \\
\hline B & Latihan push up & 0,1478 & 0,1564 & 0,220 & Normal \\
\hline
\end{tabular}

Berdasarkan hasil penghitungan uji normalitas data tes awal, tes akhir dan peningkatan kedua kelompok sampel yang dibandingkan tersebut, diperoleh nilai Lhitung dari kelompok A dan kelompok B lebih kecil dari nilai $L$ tabel $(0,220)$ pada taraf nyata $(\alpha)=0,05$ dengan $n=20$. dengan demikian kelompok sampel tersebut memiliki distribusi data normal.

Langkah ketiga, menghitung homogenitas kedua kelompok sampel dengan menggunakan uji kesamaan dua variansi. Dari hasil pengujian ini dapat diketahui apakah kedua kelompok sampel tersebut homogen atau tidak. Hasil penghitungan uji homogenitas ini dapat dilihat pada tabel 3.

\section{Tabel 3}

\section{Hasil Penghitungan Uji Homogenitas Kedua Kelompok Sampel yang Dibandingkan}

\begin{tabular}{|c|c|c|c|}
\hline Kelompok & $\mathrm{F}_{\text {hitung }}$ & $\mathrm{F}_{\text {tabel }}$ & Kesimpulan \\
\hline \hline Kelompok A & 1,09 & 2,48 & Homogen \\
\hline Kelompok B & 1,08 & 2,48 & Homogen \\
\hline
\end{tabular}

Berdasarkan hasil penghitungan uji homogenitas kesamaan dua variansi kedua kelompok sampel yang dibandingkan pada taraf nyata $(\alpha)=0,05$ dengan derajat kebebasan (dk) pembilang (14) dan dk penyebut (14) dari daftar distribusi $F$ diperoleh $F$ tabel $(14,14)$ sebesar 2,48 . Kriteria pengujian adalah: tolak hipotesis $\mathrm{H}_{0}$ jika $\mathrm{F} \geq \mathrm{F} 1 / 2\left(\mathrm{~V}_{1}, \mathrm{~V}_{2}\right)$, karena $\mathrm{F}$ hitung lebih kecil dari $\mathrm{F}$ tabel $(1,09)$ dan $(1,08)$ maka hipotesis $\mathrm{H}_{0}$ diterima untuk kelompok A dan B. Dengan kata lain kedua variansi data tersebut adalah homogen.

Normalitas dan homogenitas data dari setiap kelompok sampel telah diketahui, selanjutnya penulis melakukan pengujian dan analisis terhadap latihan bench press dan push up. Adapun hasil penghitungan dan pengujian hasil latihan kedua kelompok tersebut diperoleh dengan menggunakan uji kesamaan dua rata-rata. Hal ini digunakan karena distribusi kedua kelompok tersebut normal dan 
homogen. Hasil penghitungan dan uji signifikansi peningkatan hasil latihan pada kedua kelompok tersebut dapat dilihat pada tabel berikut.

Tabel 4

Hasil Penghitungan dan Uji Signifikansi

Peningkatan Antara Kelompok A dan Kelompok B

\begin{tabular}{|c|l|c|c|c|}
\hline Klp & \multicolumn{1}{|c|}{ Variabel penelitian } & $\mathrm{t}_{\text {hitung }}$ & $\mathrm{t}_{\text {tabel }}$ & Kesimpulan \\
\hline $\mathrm{A}$ & Latihan bench press & 6,71 & 2,05 & Signifikan \\
\hline $\mathrm{B}$ & Latihan push up & 3,64 & 2,05 & Signifkan \\
\hline
\end{tabular}

Berdasarkan hasil penghitungan uji-t pada kelompok A (latihan bench press) diperoleh nilai

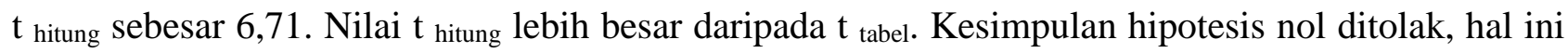
menunjukkan latihan bench press memberikan pengaruh yang signifikan terhadap keterampilan chest pass dalam permainan bola basket pada siswa SMA Negeri 3 Subang. Data yang diperoleh

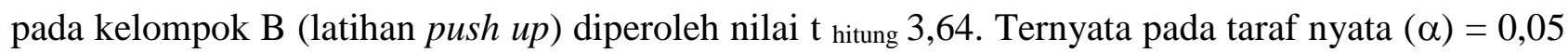
dengan derajat kebebasan $(\mathrm{dk})=28$ diperoleh nilai $\mathrm{t}$ tabel sebesar 2,05. dengan demikian nilai $\mathrm{t}$ hitung lebih besar daripada nilai $t$ tabel. Artinya hipotesis nol ditolak dan hipotesis kerja diterima.

Adapun hasil penghitungan dan uji signifikansi kedua kelompok sampel yang dibandingkan tersebut, dapat dilihat pada tabel berikut

Tabel 5

Hasil Uji Signifikansi Perbedaan Peningkatan Antara Kelompok A dengan Kelompok B

\begin{tabular}{|c|c|c|c|}
\hline Variabel penelitian & $\begin{array}{ll} & t \\
\text { hitung }\end{array}$ & tabel & $\begin{array}{l}\text { Kesi } \\
\text { mpulan }\end{array}$ \\
\hline Latihan bench press dan push up & ,21 &, $05^{2}$ & $\begin{array}{l}\text { Signi } \\
\text { fikan }\end{array}$ \\
\hline
\end{tabular}

Berdasarkan uji signifikansi perbedaan rata-rata, diperoleh hasil penghitungan dengan nilai $\mathrm{t}$ hitung sebesar 0,33 harga tabel pada taraf nyata $(\alpha)$ 0,05 dan derajat kebebasan $(\mathrm{dk})$ sebesar 2,05. Kriteria pengujian adalah tolak $\mathrm{H}_{0}$ jika $\mathrm{t}_{\text {hitung }}$ terletak antara 2,05 dan jika t mempunyai harga-harga lain. Dari penelitian di dapat $\mathrm{t}=8,21$ dan ini jelas ada dalam daerah penerimaan. Jadi $\mathrm{H}_{0}$ diterima. Artinya ada perbedaan peningkatan yang signifikan antara kelompok A dengan kelompok B. Kesimpulannya, latihan bench press memiliki perbedaan yang signifikan dengan latihan push up terhadap peningkatan keterampilan chest pass dalam permainan bola basket pada siswa SMA Negeri 3 Subang.

\section{KESIMPULAN}

Berdasarkan hasil penghitungan dan analisis data yang telah diuraikan, maka penulis dapat menarik kesimpulan dalam penelitian ini adalah sebagai berikut: 
1. Terdapat pengaruh yang signifikan dari latihan bench press terhadap hasil chest pass dalam permainan bola basket di SMA Negeri 3 Subang..

2. Terdapat pengaruh yang signifikan dari latihan push up terhadap hasil chest pass dalam permainan bola basket di SMA Negeri 3 Subang..

3. Latihan bench press lebih signifikan pengaruhnya terhadap keterampilan chest pass dibandingkan dengan latihan push up dalam permainan bola basket di SMA Negeri 3 Subang..

\section{DAFTAR PUSTAKA}

Chu, A. D. (1996). Jumping Into Plyometrics. California: Leisure Press. Campaign Illions USA

Harsono. (1988). Coaching dan Aspek-aspek Psikologis dalam Coaching. Jakarta: Tambak Kusuma. 